\title{
Structure Related a-Glucosidase Inhibitory Activity and Molecular Docking Analyses of Phenolic Compounds From Paeonia Suffruticosa
}

\section{Po-Chun Chen}

National Pingtung University of Science and Technology

Bongani Sicelo Dlamini ( $\sim$ bongani_70@hotmail.com )

National Pingtung University of Science and Technology https://orcid.org/0000-0002-4735-4741

Chiy-Rong Chen

National Taitung University

Yueh-Hsiung Kuo

China Medical University

Wen-Ling Shih

National Pingtung University of Science and Technology

Yun-Sheng Lin

Meiho University

Chien-Hsing Lee

Kaohsiung Medical University

Chi-I Chang ( $\sim$ changchii@mail.npust.edu.tw )

National Pingtung University of Science and Technology

\section{Research Article}

Keywords: Paeonia suffruticosa, enzymatic activity, a-glucosidase inhibitor, enzyme inhibition mechanism

Posted Date: July 29th, 2021

DOl: https://doi.org/10.21203/rs.3.rs-748621/v1

License: (c) (i) This work is licensed under a Creative Commons Attribution 4.0 International License. Read Full License

Version of Record: A version of this preprint was published at Medicinal Chemistry Research on January 7th, 2022. See the published version at https://doi.org/10.1007/s00044-021-02830-6. 


\section{Structure related $\alpha$-glucosidase inhibitory activity and molecular docking analyses of phenolic compounds from Paeonia suffruticosa}

Po-Chun Chen, ${ }^{1,2}$ Bongani Sicelo Dlamini, ${ }^{3}$ Chiy-Rong Chen, ${ }^{4}$ Yueh-Hsiung Kuo, ${ }^{5,6,7}$ Wen-Ling Shih, ${ }^{8}$ Yun-Sheng Lin, ${ }^{9}$ Chien-Hsing Lee, ${ }^{10,11}$ and Chi-I Chang ${ }^{8 凶}$

\section{$\square$ Chi-I Chang}

changchii@mail.npust.edu.tw

${ }^{1}$ Department of Radiation oncology, Pingtung Christian Hospital, Pingtung 90054, Taiwan

${ }^{2}$ Graduate Institute of Bioresources, National Pingtung University of Science and Technology, Pingtung 91201, Taiwan

${ }^{3}$ Department of Tropical Agriculture and International Cooperation, National Pingtung University of Science and Technology, Pingtung 91201, Taiwan

${ }^{4}$ Department of Life Science, National Taitung University, Taitung 95002, Taiwan

${ }^{5}$ Department of Chinese Pharmaceutical Sciences and Chinese Medicine Resources, China Medical University, Taichung 40402, Taiwan

${ }^{6}$ Department of Biotechnology, Asia University, Taichung 41354, Taiwan

${ }^{7}$ Chinese Medicine Research Center, China Medical University, Taichung 40402, Taiwan

${ }^{8}$ Department of Biological Science and Technology, National Pingtung University of Science and Technology, Pingtung 91201, Taiwan

${ }^{9}$ Department of Biological Science and Technology, Meiho University, Pingtung 91201, Taiwan

${ }^{10}$ Department of Pharmacology, Graduate Institute of Medicine, College of Medicine, Kaohsiung Medical University, Kaohsiung 80708, Taiwan 
${ }^{11}$ Department of Pharmacology, School of Medicine; School of Post-Baccalaureate Medicine, College of Medicine, Kaohsiung Medical University, Department of Medical Research, Kaohsiung Medical University Hospital, Kaohsiung 80708, Taiwan 


\begin{abstract}
In the continuous search for $\alpha$-glucosidase inhibitors, eleven phenolic compounds (1-11) were isolated from the root bark of Paeonia suffruticosa. Their $\alpha$-glucosidase inhibitory activity and inhibition mechanism were investigated using an in vitro inhibition assay and molecular docking studies. Compounds 2, 5, 6, and 8-11 ( $\mathrm{IC}_{50}$ between 290 and $\left.431 \mu \mathrm{M}\right)$ inhibited $\alpha$-glucosidase more effectively than the reference compound acarbose $\left(\mathrm{IC}_{50}=1463 \pm 29.5 \mu \mathrm{M}\right)$. Among them, compound 10 exhibited the highest $\alpha$-glucosidase inhibitory effect with an IC $_{50}$ value of $290.4 \pm$ 9.6 $\mu \mathrm{M}$. Compounds 2, 5,910 and 11 were found to be competitive inhibitors, while compounds $\mathbf{6}$ and $\mathbf{8}$ were noncompetitive inhibitors of $\alpha$-glucosidase. Computational analyses showed that the main binding forces between the compounds and the main residues were hydrogen bonds. The results indicated that these compounds had considerable $\alpha$-glucosidase inhibitory activity.
\end{abstract}

\title{
Graphic abstract
}
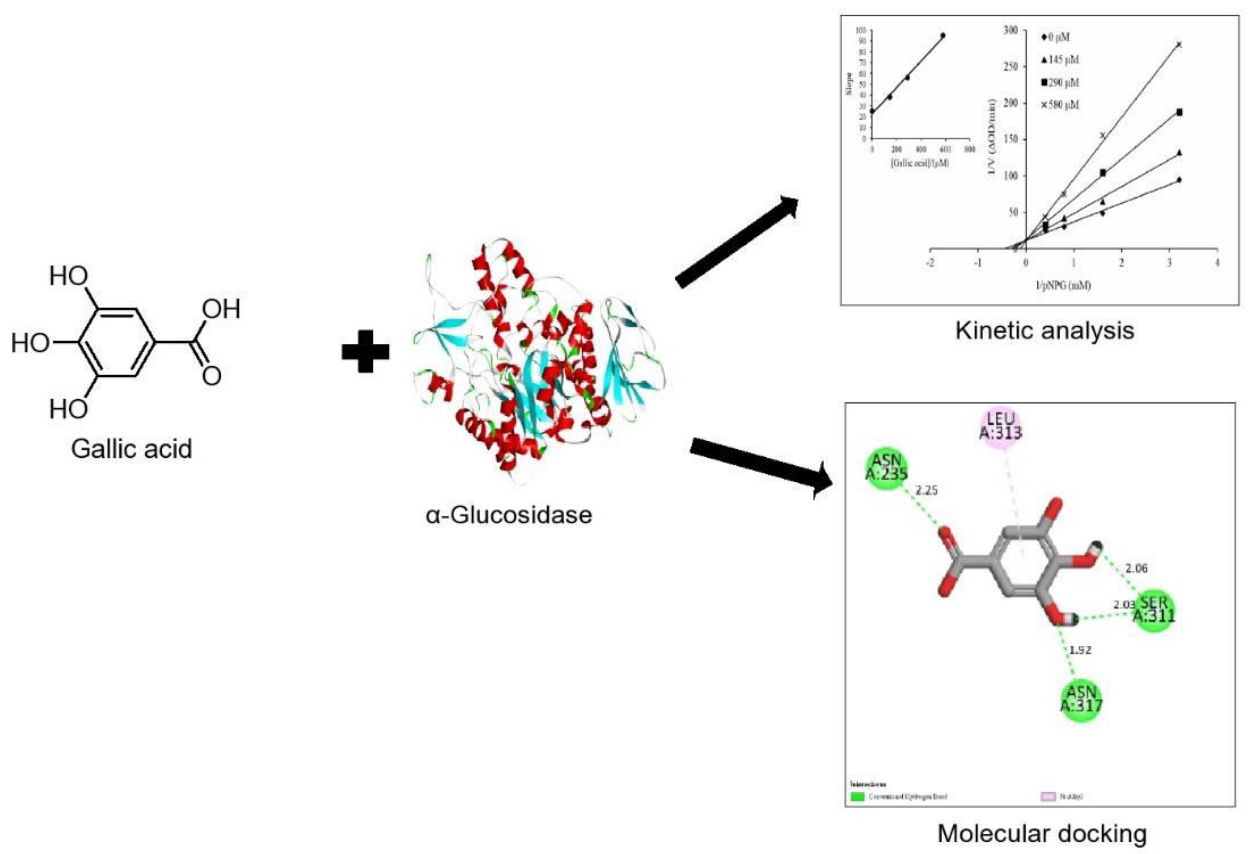
Keywords: Paeonia suffruticosa; enzymatic activity; $\alpha$-glucosidase inhibitor; enzyme inhibition mechanism

\section{Introduction}

Diabetes mellitus (DM) is a metabolic disorder characterized by excessive increases in plasma glucose levels and abnormalities in lipid and protein metabolism caused by deficient insulin secretion, insulin resistance, or both in combination over time [1]. Changes in human behaviour and lifestyle have led to a substantial increase in the prevalence of diabetes worldwide over the past century. In 2014, approximately 422 million individuals were reported by the World Health Organization (WHO) to have diabetes worldwide, with this figure projected to increase to over 650 million by 2040. [2]. Diabetes therapy is currently based on control of plasma glucose levels through adequate nutrition and the use of oral hypoglycaemic agents, but current medications have unpleasant side effects and are in short supply. Therefore, the focus in treating diabetes and managing its associated problems is shifting to widely available drugs with few side effects [3]. Medicinal plant extracts and their chemical constituents are gaining importance as potential therapies for diabetes and its sequelae because of their different modes of action and safety. Secondary metabolites of medicinal plants with pharmacological activity, including phenolic chemicals and flavonoids, are considered as potential sources of efficient and safe hypoglycaemic agents [4].

Paeonia suffruticosa (Paeoniaceae) is a medicinal plant indigenous to China with a long history of use in Traditional Chinese Medicine (TCM) and has become an important ornamental plant worldwide [5]. Traditionally, the root of $P$. suffruticosa has been utilised as a crude medicine for the treatment of extravagant blood, elimination of stagnant blood, and cardiovascular 
complications [6]. The biological activities of the plant are mainly attributed to monoterpene glycosides, such as paeoniflorin, benzoylpaeoniflorin, albiflorin, and paeoniflorigenone, and the plant is also rich in galloylglucoses, gallic acid derivatives, flavonoids, triterpenoids, and acetophenones [7]. Although the crude extract of the plant is frequently employed in antidiabetic Chinese herbal formulations, scientific studies on its antidiabetic effects are limited [8]. A comprehensive study of its bioactive constituents against key digestive enzymes responsible for the hydrolysis of carbohydrates is still lacking. The purpose of this study was to examine the antidiabetic components of the title plant. This article presents the separation, characterization, and enzyme inhibitory effect of phenolic compounds (1-11) from the root bark of P. suffruticosa (Fig. 1).

\section{Results and Discussion}

\section{Alpha-Glucosidase inhibitory activity}

The $\alpha$-glucosidase inhibitory activity of the phenolic compounds was investigated and compared with the commercial inhibitor acarbose. As shown in Table 1, all tested phenolic compounds ( IC $_{50}$ values between 290 and $431 \mu \mathrm{M}$ ) were more efficient in inhibiting $\alpha$-glucosidase compared to the reference compound acarbose ( $\mathrm{IC}_{50}$ value $1463.0 \pm 29.5 \mu \mathrm{M}$ ), except for compounds $\mathbf{1}$ and 3, which were not active at a concentration of $1000 \mu \mathrm{M}$. Among the tested compounds, compound $10\left(\mathrm{IC}_{50}\right.$ value $\left.290.4 \pm 9.6 \mu \mathrm{M}\right)$ was the most potent $\alpha$-glucosidase inhibitor, while compound $6\left(\mathrm{IC}_{50}\right.$ value $\left.431.3 \pm 11.7 \mu \mathrm{M}\right)$ showed the least inhibitory effect. Compound $\mathbf{1 0}$ contained three hydroxyl groups positioned at C-3, C-4 and C-5 and one carboxylic acid group connected to C-1. Substitution of the carboxylic acid group with an ester group resulted in a decline in the inhibitory effect of compound $\mathbf{1 1}$ compared to that of compound $\mathbf{1 0}$. When the data 
of compound $\mathbf{1 0}$ was compared with that of compound $\mathbf{2}$, it was observed that hydrogenation of the compound contributes to the effectiveness of the compound in suppressing $\alpha$-glucosidase. Moreover, a comparison of the inhibition data of compounds $\mathbf{5}$ and $\mathbf{6}$ with those of compounds 8 and 9 substantiated that the greater number of hydroxyl groups on the aromatic ring was favourable for their inhibitory activity. Compounds $\mathbf{8}$ and $\mathbf{9}$ had an additional hydroxyl group and showed lower $\mathrm{IC}_{50}$ values than compounds $\mathbf{5}$ and $\mathbf{6}$. A similar phenomenon has been observed from the literature [9], suggesting that hydroxylation may increase the inhibitory activity of flavonoid compounds. Moreover, methoxylation at C-4 and substitution of the carboxylic acid group with an acetyl group further increased the $\mathrm{IC}_{50}$ value of the compounds. The position of the hydroxyl group on the benzene ring had a minor effect on the potency of the compounds, which was observed when compound $\mathbf{8}$ was compared with $\mathbf{9}$, as well as compound 5 with 6 . Compounds $\mathbf{2}$ and $\mathbf{1 0}$ were previously reported for their $\alpha$-glucosidase inhibitory activity with comparable $\mathrm{IC}_{50}$ values of $424.8 \pm 30.40 \mu \mathrm{M}$ and $296.2 \pm 17.63 \mu \mathrm{M}$, respectively [10], which were close to our result.

\section{Inhibition mechanisms of $\alpha$-glucosidase}

The nature of inhibition on $\alpha$-glucosidase of phenolic compounds was investigated using Lineweaver-Burk plots [11]. As shown in Fig. 2, all the double reciprocal plots of the compounds $(\mathbf{2}, \mathbf{5}, \mathbf{9}, \mathbf{1 0}$, and $\mathbf{1 1})$ intersected on the y-axis, indicating competitive inhibition of $\alpha$ glucosidase. The values of $\mathrm{K}_{\mathrm{m}}$ increased and the values of $\mathrm{V}_{\mathrm{m}}$ remained constant as shown by the increasing slope and the constant y-intercept of the curves as the concentration of the compounds increased, confirming that these compounds induce competitive inhibition.

In Fig. 2, the data lines of compounds $\mathbf{6}$ and $\mathbf{8}$ crossed on the horizontal axis with a constant $\mathrm{x}$-intercept. Additionally, both the y-intercept and gradient of the graphs increased with the 
increase in the concentration of the compounds, indicating that the $\mathrm{V}_{\mathrm{m}}$ values decreased and the $\mathrm{K}_{\mathrm{m}}$ values were constant. As shown in Table 1, the equilibrium constants $\left(\mathrm{K}_{\mathrm{i}}\right.$ and $\left.\mathrm{K}_{\mathrm{is}}\right)$ were the same. These results indicated that compounds $\mathbf{6}$ and $\mathbf{8}$ were noncompetitive inhibitors of $\alpha$ glucosidase. Moreover, the secondary plots (insert of Fig. 2) of the slope against the concentration of the compounds fitted linearly, suggesting that the compounds bind to a single inhibition site on the enzyme [12].

\section{Molecular docking analysis}

Computer-assisted docking was conducted to analyse the interaction mechanisms of the compounds with $\alpha$-glucosidase by visualising binding in the receptor-ligand composite [13]. As shown in Fig. 3A and B, the compounds were located at the active binding site of $\alpha$-glucosidase. The major amino acid residues involved in the interaction of the compounds and $\alpha$-glucosidase were Asp233, Asn235, Ser311, Leu313, Asn317, Val319, and Lys432, and these residues were found to be crucial for the catalytic mechanism [12]. All compounds formed $\pi$-interactions with the amino acid residue Leu313, and compounds $\mathbf{5}$ and $\mathbf{1 1}$ also formed $\pi$-interactions with Val319. In Fig. 3C, compound 2 was stabilized by forming hydrogen bonds at the $\mathrm{C} 4-\mathrm{OH}$ and carboxyl group with amino acid residues Ser311 (2.07 ̊), Asn317 (1.99 ̊), and Asp233 (1.98 A). The calculated binding energy was $-0.32 \mathrm{Kcal} / \mathrm{mol}$. In Fig. 3D, compound 5 interacted with Asp233 (2.00 ̊), Asn235 (2.91 A) and Asn317 (2.04 A) via hydrogen bonding. The compound showed higher binding affinity than compounds $\mathbf{2}$ and $\mathbf{5}$ with the binding energy of -0.38 $\mathrm{Kcal} / \mathrm{mol}$. In Fig. 3E, compound 6 produced two hydrogen bonds at $\mathrm{C} 3-\mathrm{OH}$ and the carbonyl group with Asp233 (1.99 $)$ and Asn317 (1.98 $)$ with a calculated binding energy, -0.28 $\mathrm{Kcal} / \mathrm{mol}$. The binding energy was in agreement with the experimental results, showing that compound $\mathbf{6}$ is the compound with lower affinity. 
In the case of compound $\mathbf{8}$, two hydrogen bonds were generated at $\mathrm{C} 2-\mathrm{OH}$ and the carbonyl group with Ser311 and Lys432, their distances were $2.03 \AA$ and $1.81 \AA$, respectively (Fig. 3F). Compound 9 was stabilized by the interactions of Asn317 with $\mathrm{C} 2-\mathrm{OH}$ and the carbonyl group with distances of $2.13 \AA$ and $2.00 \AA$, and C3-OH interacted with Asp233 (2.15 Å) through hydrogen bonds (Fig. 3G). Compound 10 formed hydrogen bonds with Asn235, Ser311, and Asn317, while compound 11 interacted with Asp233 and Asn317 through hydrogen bonds (Fig. 3H and I). The more hydrogen bonds formed between the compounds and the amino acids, the higher the affinity of the compounds. The binding energies of compounds $\mathbf{8}$ and $\mathbf{9}$ were -0.87 and $-0.92 \mathrm{Kcal} / \mathrm{mol}$, while the values of compounds $\mathbf{1 0}$ and $\mathbf{1 1}$ were -1.34 and -1.17 $\mathrm{Kcal} / \mathrm{mol}$, respectively. The results were in agreement with the kinetic analysis, which showed that compound $\mathbf{1 0}$ had the highest affinity, while compounds $\mathbf{8}$ and $\mathbf{9}$ had a similar effect.

\section{Conclusions}

The results of enzymatic activities and molecular docking suggested that hydroxylation of the aromatic ring was favourable for the inhibitory effect of phenolic compounds compared to methoxylation or hydrogenation. In addition, the position of the hydroxyl group and the substitution of the carboxyl group were important in improving the inhibitory activity of the compounds. The most effective phenolic compound found was compound $\mathbf{1 0}$ with the most hydroxyl groups and carboxyl groups. This research contributes significantly to the study of direct $\alpha$-glucosidase inhibitory activity by phenolic compounds and provides detailed information on their interactions with $\alpha$-glucosidase. 


\section{Experimental}

\section{General experimental procedures}

High performance liquid chromatography (HPLC) was conducted on a Hitachi L-7100 system coupled with Waters R410 differential refractometer using a Themo Hypersil-Keystone BETASIL Silica-100 column (5 $\mu \mathrm{m}, 250 \times 10 \mathrm{~mm})$. Silica gel (63-200 mesh, Merck) was used for column chromatography. ${ }^{1} \mathrm{H}$ and ${ }^{13} \mathrm{C}$ NMR spectra were recorded on a Varian-Unity-Plus-400 spectrometer in DMSO- $\mathrm{d}_{6}$ or $\mathrm{CDCl}_{3}$ using residual solvent signals as reference. TLC was conducted on a silica gel $60 \mathrm{~F}_{254}(0.2 \mathrm{~mm}$, Merck), illuminated under UV light (254 and $365 \mathrm{~nm})$ and developed with $10 \% \mathrm{H}_{2} \mathrm{SO}_{4}$ in ethanol (v/v). The absorbance was recorded in a Thermo Fisher Scientific (Ratastie 2, FI-01620 Vantaa, Finland) spectrophotometer. $\alpha$-Glucosidase from Saccharomyces cerevisiae was purchased from Sigma Aldrich (St. Louis, MO, USA). Acarbose, and 4- $p$-nitrophenyl- $\alpha$-D-glucopyranoside (pNPG) were obtained from Acros Organics Company. All organic solvents were obtained from American Tedia Company and Acros Organics Company.

\section{Plant material}

The roots bark of $P$. suffruticosa was collected from China's Anhui province and was purchased from traders. Samples were authenticated by Prof. Sheng-Zehn Yang, Herbarium Curator, Department of Forestry, National Pingtung University of Science and Technology. A voucher specimen (No. BT360) was deposited at the herbarium of the Department of Biological Science and Technology. 


\section{Extraction and isolation}

The root bark $(3.6 \mathrm{~kg})$ of $P$. suffruticosa was pulverised and extracted with methanol $(3 \times 20 \mathrm{~L})$ at room temperature. The methanol was removed from the extract using a vacuum rotary evaporator to give crude extract (720 g), which was then suspended in water and separated sequentially with ethyl acetate (EtOAc) and $n$-butanol $(n$-BuOH) to obtain EtOAc $(105 \mathrm{~g}), n$ $\mathrm{BuOH}$ (320 g), and water (260 g) soluble fractions. The EtOAc fraction was further fractionated on a column chromatography $(7 \times 90 \mathrm{~cm})$ using a gradient solvent mixture of hexane/EtOAc (100:0 to 0:100, v/v) and EtOAc/MeOH (100:0 to 0:100, v/v) to give twenty-three fractions (Fr. 1-23). Fr.4 (1400 mg) was further purified by washing and recrystallization with $n$ hexane/dichloromethane to obtain compound 5 (610 mg). Fr.10 (302 mg) was separated on a semi-preparative normal phase HPLC eluted with dichloromethane/EtOAc $(30: 1, \mathrm{v} / \mathrm{v})$ to obtain thirteen subfractions (Fr.10-1-Fr.10-13). Fr.10-7 (34 mg) was further purified on a semipreparative normal phase HPLC eluting with dichloromethane/isopropanol (100:1, v/v) to afford compounds 4 (1.5 mg) and 7 (1.6 mg). Fr.11 (1260 mg) was fractionated on a semi-preparative normal phase HPLC with a mobile phase of dichloromethane/EtOAc $(30: 1, \mathrm{v} / \mathrm{v})$ into ten subfractions (Fr.11-1-Fr.11-10). Fr.11-3 (460 mg) was further separated on a HPLC eluted with dichloromethane/isopropanol (100:1, v/v) to obtain six subfractions (Fr.11-3A-Fr.11-3F). Fr.113C (60 mg) was purified on a HPLC using a mobile phase of $n$-hexane/dichloromethane/acetone (7/7/1, v/v) to obtain compound $8(10 \mathrm{mg})$. Fr.13 $(850 \mathrm{mg})$ was separated on a HPLC using a solvent mixture of dichloromethane/EtOAc (30:1, v/v) into nine subfractions (Fr.13-1-Fr.13-9). Further separation of subfraction Fr.13-6 (220 mg) on a HPLC gave eight subfractions (Fr.136A-Fr.13-6H). Fr.13-6C (40 mg) was further purified on a HPLC eluted with $n$ hexane/dichloromethane/acetone (7/7/1, v/v) to afford compound 6 (5 mg). Fr.15 (1600 mg) was 
purified on a HPLC using a mobile phase of dichloromethane/EtOAc $(30: 1, \mathrm{v} / \mathrm{v})$ to isolate compound 1 (70 mg). Fr.16 (1260 mg) was separated on a HPLC eluted with dichloromethane/EtOAc (100:1, v/v) to obtain twelve fractions (Fr.16-1-Fr.16-12). Fr.16-1 (35 mg) was further purified on a HPLC using $n$-hexane/dichloromethane/acetone $(7 / 7 / 1, \mathrm{v} / \mathrm{v})$ to afford compound $3(2 \mathrm{mg})$. Fr.17 (380 mg) was purified on a HPLC eluting with $n$ hexane/dichloromethane/acetone (7/7/1, v/v) to give four subfractions (Fr.17-1- Fr.17-4). Fr.17$1(35 \mathrm{mg})$ was further purified on HPLC using dichloromethane/isopropanol (100/1, v/v) to obtain compound 9 (3 mg). Fr.19 (800 mg) was washed and recrystallized with dichloromethane and methanol to give compound $\mathbf{1 1}(75 \mathrm{mg})$. Fr.20 (3200 mg) was subjected to silica gel column chromatography $(2 \times 50 \mathrm{~cm})$ eluted with dichloromethane/EtOAc $(10 / 1, \mathrm{v} / \mathrm{v})$ to obtain compound $10(810 \mathrm{mg})$.

Benzoic acid (1): Colourless crystal; ${ }^{1} \mathrm{H}-\mathrm{NMR}\left(\mathrm{CDCl}_{3}, 400 \mathrm{MHz}\right) \delta 8.12(2 \mathrm{H}, \mathrm{d}, J=8.4 \mathrm{~Hz}, \mathrm{H}-$ 2, 6), $7.60(1 \mathrm{H}, \mathrm{d}, J=7.6 \mathrm{~Hz}, \mathrm{H}-4), 7.47(2 \mathrm{H}, \mathrm{d}, J=8.4 \mathrm{~Hz}, \mathrm{H}-3,5) .{ }^{13} \mathrm{C} \mathrm{NMR}\left(\mathrm{CDCl}_{3}, 100\right.$ MHz) $\delta$ 172.3, 133.8, 130.2, 129.3, 128.5; EI-MS m/z (\%): $122[\mathrm{M}]^{+}(100), 105(95), 77(35)$, 51(8) [14].

4-Hydroxybenzoic acid (2): White crystal; ${ }^{1} \mathrm{H}-\mathrm{NMR}$ (DMSO- $\left.d_{6}, 400 \mathrm{MHz}\right) \delta(\mathrm{ppm}): 10.23(1 \mathrm{H}$, s, 4-OH), $7.78(2 \mathrm{H}, \mathrm{d}, J=8.8 \mathrm{~Hz}, \mathrm{H}-3,5), 6.81(1 \mathrm{H}, \mathrm{d}, J=8.8 \mathrm{~Hz}, \mathrm{H}-2,6) ;$ EI-MS: m/z (\%): 138 $[\mathrm{M}]^{+}(70), 121(100), 93(23), 65(17)[15]$.

4-Methoxybenzoic acid (3): White crystal; ${ }^{1} \mathrm{H}-\mathrm{NMR}\left(\mathrm{CDCl}_{3}, 400 \mathrm{MHz}\right) \delta 8.05(2 \mathrm{H}, \mathrm{d}, J=8.4$ $\mathrm{Hz}, \mathrm{H}-2,6), 6.92(2 \mathrm{H}, \mathrm{d}, J=8.8 \mathrm{~Hz}, \mathrm{H}-3,5), 3.86\left(3 \mathrm{H}, \mathrm{s}, 4-\mathrm{OCH}_{3}\right) \cdot{ }^{13} \mathrm{C} \mathrm{NMR}\left(\mathrm{CDCl}_{3}, 100 \mathrm{MHz}\right)$ $\delta$ 170.3, 163.9, 132.3, 121.7, 113.7, 55.5; EI-MS m/z (\%): $152[\mathrm{M}]^{+}(65), 151(100), 135(52)$, 123(18), 84(10), 77(15), 49(11) [16]. 
1-(2,4-Dihydroxyphenyl)ethanone (4): Colorless needless; ${ }^{1} \mathrm{H}-\mathrm{NMR}\left(\mathrm{CDCl}_{3}, 400 \mathrm{MHz}\right) \delta 12.68$ (1H, s, 2-OH), $7.62(1 \mathrm{H}, \mathrm{d}, J=8.4 \mathrm{~Hz}, \mathrm{H}-6), 6.38(1 \mathrm{H}, \mathrm{d}, J=8.4,2.4 \mathrm{~Hz}, \mathrm{H}-5), 6.35(1 \mathrm{H}, \mathrm{d}, J=$ $2.4 \mathrm{~Hz}, \mathrm{H}-3), 2.54\left(3 \mathrm{H}, \mathrm{s}, 1-\mathrm{COCH}_{3}\right) .{ }^{13} \mathrm{C} \mathrm{NMR}\left(\mathrm{CDCl}_{3}, 100 \mathrm{MHz}\right) \delta 202.7,165.1,162.7,150.4$, 133.0, 114.2, 109.7, 103.4, 26.2; EI-MS m/z (\%): $152[\mathrm{M}]^{+}$(43), 137 (100), 84(10), 81(10), 49(10) [17].

1-(2-Hydroxy-4-methoxyphenyl)ethanone (Paeonol) (5): White powder; ${ }^{1} \mathrm{H}-\mathrm{NMR}\left(\mathrm{CDCl}_{3}\right.$, $400 \mathrm{MHz}) \delta 12.72(1 \mathrm{H}, \mathrm{s}, 2-\mathrm{OH}), 7.60(1 \mathrm{H}, \mathrm{d}, J=8.8 \mathrm{~Hz}, \mathrm{H}-6), 6.41$ (1H, dd, $J=8.8,2.4 \mathrm{~Hz}, \mathrm{H}-$ 5), $6.38(1 \mathrm{H}, \mathrm{d}, J=2.4 \mathrm{~Hz}, \mathrm{H}-3), 3.80\left(3 \mathrm{H}, \mathrm{s}, 4-\mathrm{OCH}_{3}\right), 2.52\left(3 \mathrm{H}, \mathrm{s}, 1-\mathrm{COCH}_{3}\right) .{ }^{13} \mathrm{C} \mathrm{NMR}$ $\left(\mathrm{CDCl}_{3}, 100 \mathrm{MHz}\right) \delta 202.5,166.0,165.2,132.2,113.8,107.6,100.8,55.5,26.2 ;$ EI-MS m/z (\%): $166[\mathrm{M}]^{+}(24), 151(69), 86(61), 84(95), 51(34), 49(100)[18]$.

1-(3-Hydroxy-4-methoxyphenyl)ethanone (Isoacetovanillon) (6). White solids; ${ }^{1} \mathrm{H}-\mathrm{NMR}$ $\left(\mathrm{CDCl}_{3}, 400 \mathrm{MHz}\right) \delta 7.51(1 \mathrm{H}, \mathrm{dd}, J=8.8,2.0 \mathrm{~Hz}, \mathrm{H}-6), 7.49(1 \mathrm{H}, \mathrm{d}, J=2.0 \mathrm{~Hz}, \mathrm{H}-2), 6.85(1 \mathrm{H}$, $\mathrm{d}, J=8.8 \mathrm{~Hz}, \mathrm{H}-5), 6.04(1 \mathrm{H}, \mathrm{s}, 3-\mathrm{OH}), 3.91\left(3 \mathrm{H}, \mathrm{s}, 4-\mathrm{OCH}_{3}\right), 2.50\left(3 \mathrm{H}, \mathrm{s}, 1-\mathrm{COCH}_{3}\right) .{ }^{13} \mathrm{C} \mathrm{NMR}$ $\left(\mathrm{CDCl}_{3}, 100 \mathrm{MHz}\right) \delta 197.2,150.7,145.3,130.8,121.8,114.4,109.8,56.0,26.3 ;$ EI-MS m/z (\%): $166[\mathrm{M}]^{+}(46), 151(100)[19]$.

1-(2,5-Dihydroxy-4-methylphenyl)ethanone (7): Yellow solids; ${ }^{1} \mathrm{H}-\mathrm{NMR}\left(\mathrm{CDCl}_{3}, 400 \mathrm{MHz}\right) \delta$ $11.85(1 \mathrm{H}, \mathrm{s}, 2-\mathrm{OH}), 7.08$ (1H, s, H-6), $6.75(1 \mathrm{H}, \mathrm{s}, \mathrm{H}-2), 4.69$ (1H, brs, 5-OH), 2.54 (3H, s, 1 $\left.\mathrm{COCH}_{3}\right), 2.25\left(3 \mathrm{H}, \mathrm{s}, 4-\mathrm{CH}_{3}\right) .{ }^{13} \mathrm{C} \mathrm{NMR}\left(\mathrm{CDCl}_{3}, 100 \mathrm{MHz}\right) \delta 203.4,156.6,146.0,135.7,120.0$, 117.5, 114.8, 26.6, 16.7; EI-MS m/z (\%): $166[\mathrm{M}]^{+}$(50), 152 (12), 151 (100), 123(12) [20].

1-(2,5-Dihydroxy-4-methoxyphenyl)ethanone (8): Yellow crystal; ${ }^{1} \mathrm{H}-\mathrm{NMR}\left(\mathrm{CDCl}_{3}, 400\right.$ MHz) $\delta 12.47(1 \mathrm{H}, \mathrm{s}, 2-\mathrm{OH}), 7.17$ (1H, s, H-6), 6.41 (1H, s, H-2), 3.89 (3H, s, 4-OCH $), 2.50$ $\left(3 \mathrm{H}, \mathrm{s}, 1-\mathrm{COCH}_{3}\right) .{ }^{13} \mathrm{C} \mathrm{NMR}\left(\mathrm{CDCl}_{3}, 100 \mathrm{MHz}\right) \delta 202.7,158.8,153.7,137.9,113.9,112.4,99.7$, 56.1, 26.4; EI-MS m/z (\%): $182[\mathrm{M}]^{+}(56), 167$ (100), 111(9), 69(8) [21]. 
1-(2,3-Dihydroxy-4-methoxyphenyl)ethanone (9). Light yellow powder; ${ }^{1} \mathrm{H}-\mathrm{NMR}\left(\mathrm{CDCl}_{3}, 400\right.$ MHz) $\delta 12.48(1 \mathrm{H}, \mathrm{s}, 2-\mathrm{OH}), 7.31(1 \mathrm{H}, \mathrm{d}, J=8.8 \mathrm{~Hz}, \mathrm{H}-6), 6.49(1 \mathrm{H}, \mathrm{d}, J=8.8 \mathrm{~Hz}, \mathrm{H}-5), 5.54$

(1H, brs, 3-OH), $3.94\left(3 \mathrm{H}, \mathrm{s}, 4-\mathrm{OCH}_{3}\right), 2.56\left(3 \mathrm{H}, \mathrm{s}, 1-\mathrm{COCH}_{3}\right) .{ }^{13} \mathrm{C} \mathrm{NMR}\left(\mathrm{CDCl}_{3}, 100 \mathrm{MHz}\right) \delta$ 203.5, 152.0, 150.2, 133.3, 122.7, 114.7, 102.7, 56.2, 26.3; EI-MS m/z (\%): $182[\mathrm{M}]^{+}(47), 167$ (100), 152(13) [22].

Gallic acid (10): White crystals; ${ }^{1} \mathrm{H}-\mathrm{NMR}\left(\mathrm{DMSO}-d_{6}, 400 \mathrm{MHz}\right) \delta 6.90(2 \mathrm{H}, \mathrm{s}, \mathrm{H}-2,6) .{ }^{13} \mathrm{C}$ NMR (DMSO- $\left.d_{6}, 100 \mathrm{MHz}\right) \delta 167.6,145.5,138.1,120.5,108.8 ; \mathrm{EI}-\mathrm{MS}$ m/z (\%): $170[\mathrm{M}]^{+}$ (100), 153(89), 125(20), 79(18), 45(42) [23].

Methyl gallate (11): Pale yellowish crystal; ${ }^{1} \mathrm{H}-\mathrm{NMR}\left(\mathrm{DMSO}-d_{6}, 400 \mathrm{MHz}\right) \delta 6.92(2 \mathrm{H}, \mathrm{s}, \mathrm{H}-2$, 6), $3.72\left(3 \mathrm{H}, \mathrm{s}, 1-\mathrm{COOCH}_{3}\right) .{ }^{13} \mathrm{C} \mathrm{NMR}\left(\mathrm{DMSO}-d_{6}, 100 \mathrm{MHz}\right) \delta 166.4,145.6,138.5,119.3$, 108.5, 51.7; EI-MS m/z (\%): 184 [M] (44), 153 (100), 125(32), 79(50), 51(30) [24].

\section{Alpha-Glucosidase inhibition assay}

The $\alpha$-glucosidase inhibitory activity of the tested compounds was measured following the methods of [25] and [26] with slight modifications. Briefly, $10 \mu \mathrm{L}$ of $\alpha$-glucosidase, $5 \mu \mathrm{L}$ of the compounds solution and $170 \mu \mathrm{L}$ of phosphate buffer $(0.2 \mathrm{M}, \mathrm{pH} 6.8)$ were mixed and incubated at $37^{\circ} \mathrm{C}$ for $5 \mathrm{~min}$. After incubation, the reaction was initiated with the addition of $10 \mu \mathrm{L}$ of pNPG solution into the reaction mixture and incubated for $60 \mathrm{~min}$ at $37^{\circ} \mathrm{C}$. After incubation, the reaction was stopped by adding $5 \mu \mathrm{L}$ of $\mathrm{NaOH}$ and the absorbance was measured at $405 \mathrm{~nm}$ using a microplate reader. The enzyme $(1 \mathrm{U} / \mathrm{mL})$ and substrate $(25 \mathrm{mM})$ stock solutions were prepared in phosphate buffer and $\mathrm{NaOH}$ was dissolved in distilled water, while the compounds $(0-1000 \mu \mathrm{M})$ and acarbose $(0-1500 \mu \mathrm{M})$ were dissolved in DMSO. The amount of DMSO (2.5\%) did not interfere with the experiment. The percentage of inhibition was calculated using equation 1 . 


$$
\text { Inhibition effect }(\%)=\left[\left(\mathrm{A}_{c}-\mathrm{A}_{\mathrm{s}}\right) / \mathrm{A}_{\mathrm{c}}\right] \times 100
$$

Where $A_{s}$ and $A_{c}$ represent the enzyme reaction with and without the samples or standard, respectively.

\section{Mode of inhibition against $\alpha$-glucosidase}

The same procedure as the enzyme inhibition assay was used to analyse the inhibition mechanisms of the compounds: $2(0-800 \mu \mathrm{M}), 5(0-820 \mu \mathrm{M}), 6(0-880 \mu \mathrm{M}), 8(0-760 \mu \mathrm{M}), 9(0-$ $740 \mu \mathrm{M}), \mathbf{1 0}(0-580 \mu \mathrm{M})$, and $\mathbf{1 1}(0-730 \mu \mathrm{M})$. The pNPG concentrations ranged from 0 to 1.25 $\mathrm{mM}$, while the concentration of $\alpha$-glucosidase was fixed $(0.05 \mathrm{U} / \mathrm{mL})$. Kinetic parameters were determined using Lineweaver-Burk plots and described as follows [27, 28].

Competitive type:

$$
\frac{1}{\mathrm{v}}=\frac{\mathrm{K}_{\mathrm{m}}}{\mathrm{V}_{\max }}\left(1+\frac{[\mathrm{I}]}{\mathrm{K}_{\mathrm{i}}}\right) \frac{1}{[\mathrm{~S}]}+\frac{1}{\mathrm{~V}_{\max }}
$$

Non-competitive and mixed type:

$$
\frac{1}{\mathrm{v}}=\frac{\mathrm{K}_{\mathrm{m}}}{\mathrm{V}_{\max }}\left(1+\frac{[\mathrm{I}]}{\mathrm{K}_{\mathrm{i}}}\right) \frac{1}{[\mathrm{~S}]}+\frac{1}{\mathrm{~V}_{\max }}\left(1+\frac{[\mathrm{I}]}{\mathrm{K}_{\mathrm{is}}}\right)
$$

Secondary plots were determined as follows

$$
\begin{gathered}
\text { Slope }=\frac{\mathrm{K}_{\mathrm{m}}}{\mathrm{V}_{\max }}+\frac{\mathrm{K}_{\mathrm{m}}[\mathrm{I}]}{\mathrm{V}_{\max } \mathrm{K}_{\mathrm{i}}} \\
\text { Y-intercept }=\frac{1}{\mathrm{~V}_{\max }^{a p p}}=\frac{1}{\mathrm{~V}_{\max }}+\frac{1}{\mathrm{~K}_{\mathrm{is}} \mathrm{V}_{\max }}[\mathrm{I}]
\end{gathered}
$$

Here $K_{i}$ and $K_{\text {is }}$ indicate the equilibrium constant of the inhibitor to the enzyme and the enzyme-substrate composite, respectively. $\mathrm{K}_{\mathrm{m}}$ represent the Michaelis-Menten constant, $\mathrm{v}$ represents the enzyme reaction velocity, $[\mathrm{I}]$ and $[\mathrm{S}]$ represent the concentration of the compounds and pNPG, respectively. 


\section{Molecular docking}

The interactions between $\alpha$-glucosidase and phenolic compounds were studied by computer simulation. The structure of $\alpha$-glucosidase (PDB code: 3A4A) was taken from Protein Data Bank (http://www.rcsb.org/pdb). Ligands and water were removed from the enzyme to create a stable receptor for the phenolic compounds. The angle of the lattice box was 90 points (x, y, and z) with a spacing of $0.5 \AA$, and the lattice box location was set at $11.9,-16.3$, and $15.5 \AA$ (x, y, and z). ChemDraw Pro 5.0 software was used to create the three-dimensional structures of the compounds. Binding events were visually analysed using Discovery Studio 3.0 software and geometry minimization was performed using a CDOCKER (CHARMm-based DOCKER). The hydrogen bonding, pi-pi stacking and hydrophobic interactions generated between the phenolic compounds and the major residues in the active site of $\alpha$-glucosidase were obtained from the docking results.

\section{Statistical Analysis}

SPSS version 25 was used for all statistical analyses. Compounds were statistically compared using one-way analysis of variance (ANOVA), and differences between means were assessed using Tukey's HSD test, with p values less than 0.05 considered significant. Each figure reflects three separate experiments, and results are reported as mean \pm standard error of the mean (SEM). The variable slope nonlinear regression method was used to determine $\mathrm{IC}_{50}$ values (GraphPad Prism 5.0.1, GraphPad Software, San Diego, California USA).

\section{Acknowledgements}

We thank Ms Lih-Mei Sheu and Ms Shu-Chi Lin, Instrumentation Centre of the College of Science, National Chung Hsing University and National Tsing Hua University for MS 
measurements. The nuclear magnetic resonance spectrometer (NMR) was performed in the

Precision Instruments Centre of National Pingtung University of Science and Technology.

\section{Funding}

This work was supported by the Ministry of Science and Technology of Taiwan (Grants MOST

105-2320-B-020-002-MY3 and MOST 108-2320-B-020-003) and NPUST-KMU Joint Research

Project (KP-109005).

\section{Disclosure statement}

The authors declare no conflict of interest.

\section{Data Availability}

The NMR and MS spectra of the compounds are available as supplementary material.

\section{References}

1. Tang X, Olatunji OJ, Zhou Y, Hou X. Allium tuberosum: Antidiabetic and hepatoprotective activities. Food Res Int. 2017;102:681-689. https://doi.org/10.1016/j.foodres.2017.08.034

2. Organization WH. 2016. Global report on diabetes: Executive summary. World Health Organization; 2016.

3. Ye JP. Challenges in drug discovery for thiazolidinedione substitute. Acta Pharm Sin B. 2011;1:137-142. https://doi.org/10.1016/j.apsb.2011.06.011

4. Tang D, Chen QB, Xin XL, Aisa HA. Anti-diabetic effect of three new norditerpenoid alkaloids in vitro and potential mechanism via PI3K/AKT signaling pathway. Biomed Pharmacother. 2017;87:145-152. https://doi.org/10.1016/j.biopha.2016.12.058 
5. De-Yuan H, Kai-Yu P. A revision of the Paeonia suffruticosa complex (Paeoniaceae). Nord J Bot. 1999;19:289-300. https://doi.org/10.1111/j.1756-1051.1999.tb01115.x

6. Huang Q, Chen JJ, Pan Y, He XF, Wang Y, Zhang XM et al. Chemical profiling and antidiabetic potency of Paeonia delavayi: Comparison between different parts and constituents. J Pharm Biomed Anal. 2021;198:113998.

https://doi.org/10.1016/j.jpba.2021.113998

7. Pan Y, Gao Z, Huang XY, Chen JJ, Geng CA. Chemical and biological comparison of different parts of Maeonia suffruticosa (Mudan) based on LCMS-IT-TOF and multievaluation in vitro. Ind Crops Prod. 2020;144:112028. https://doi.org/10.1016/j.indcrop.2019.112028

8. Lau C, Chan C, Chan Y, Lau K, Lau T, Lam F et al. Pharmacological investigations of the anti-diabetic effect of Cortex Moutan and its active component paeonol. Phytomedicine. 2007;14:778-784. https://doi.org/10.1016/j.phymed.2007.01.007

9. Yang J, Wang X, Zhang C, Ma L, Wei T, Zhao Y et al. Comparative study of inhibition mechanisms of structurally different flavonoid compounds on $\alpha$-glucosidase and synergistic effect with acarbose. Food Chem. 2021;347:129056. https://doi.org/10.1016/j.foodchem.2021.129056

10. Tan Y, Chang SK, Zhang Y. Comparison of $\alpha$-amylase, $\alpha$-glucosidase and lipase inhibitory activity of the phenolic substances in two black legumes of different genera. Food Chem. 2017;214:259-268. https://doi.org/10.1016/j.foodchem.2016.06.100

11. Zhang CC, Geng CA, Huang XY, Zhang XM, Chen JJ. Antidiabetic stilbenes from peony seeds with PTP1B, $\alpha$-glucosidase, and DPPIV inhibitory activities. J Agric Food Chem. 2019;67:6765-6772. https://doi.org/10.1021/acs.jafc.9b01193 
12. Zeng L, Ding H, Hu X, Zhang G, Gong D. Galangin inhibits $\alpha$-glucosidase activity and formation of non-enzymatic glycation products. Food Chem. 2019;271:70-79. https://doi.org/10.1016/j.foodchem.2018.07.148

13. Zeng L, Zhang G, Lin S, Gong D. Inhibitory mechanism of apigenin on $\alpha$-glucosidase and synergy analysis of flavonoids. J Agric Food Chem. 2016;64:6939-6949. https://doi.org/10.1021/acs.jafc.6b02314

14. Nandi J, Hutcheson EL, Leadbeater NE. Combining photoredox catalysis and oxoammonium cations for the oxidation of aromatic alcohols to carboxylic acids. Tetrahedron Lett. 2021;63:152632. https://doi.org/10.1016/j.tetlet.2020.152632

15. Sang D, Yue H, Fu Y, Tian J. Cleavage of carboxylic esters by aluminum and iodine. J Org Chem. 2021;86:4254-4261. https://doi.org/10.1021/acs.joc.1c00034

16. Sun C, Zheng L, Xu W, Dushkin AV, Su W. Mechanochemical cleavage of lignin models and lignin via oxidation and a subsequent base-catalyzed strategy. Green Chem. 2020;22:3489-3494. https://doi.org/10.1039/D0GC00372G

17. Lin $\mathrm{Y}, \mathrm{Wu} \mathrm{X}$, Feng S, Jiang G, Luo J, Zhou S et al. Five unique compounds: Xyloketals from mangrove fungus Xylaria sp. From the South China sea coast. J Org Chem. 2001;66:62526256. https://doi.org/10.1021/jo015522r

18. Anh HLT, Cuc NT, Tai BH, Yen PH, Nhiem NX, Thao DT et al. Synthesis of chromonylthiazolidines and their cytotoxicity to human cancer cell lines. Molecules. 2015;20:1151-1160. https://doi.org/10.3390/molecules20011151

19. Ghanadian M, Sadraei H, Yousuf S, Asghari G, Choudhary MI, Jahed M. New diterpene polyester and phenolic compounds from Pycnocycla spinosa Decne. Ex Boiss with relaxant 
effects on KCl-induced contraction in rat ileum. Phytochem Lett. 2014;7:57-61. https://doi.org/10.1016/j.phytol.2013.09.016

20. Sarkar D, Ghosh MK. Stereoselective synthesis of Heliannuol G. Tetrahedron Lett. 2017;58:4336-4339. https://doi.org/10.1016/j.tetlet.2017.09.081

21. Usui Tateo KH, Hayakawa Ichiro, Chinen Takumi, Shioda Shuya, inventor. 2016. Microtubule polymerization inhibitor. Japan patent JP2016124829.

22. Lin J, Zhang W, Jiang N, Niu Z, Bao K, Zhang L et al. Total synthesis of Bulbophylol-B. J Nat Prod. 2008;71:1938-1941. https://doi.org/10.1021/np800226n

23. Zago AM, Carvalho FB, Gutierres JM, Bohnert C, Fernandes MdC, Morandini LM et al. A phytochemical study of the Cuphea glutinosa from Southern Brazil: $\mathrm{Na}^{+}, \mathrm{K}^{+}$-ATPase activity inhibition and antioxidant properties. Nat Prod Res. 2019;33:3426-3431. https://doi.org/10.1080/14786419.2018.1477143

24. Lima TC, Ferreira AR, Silva DF, Lima EO, De Sousa DP. Antifungal activity of cinnamic acid and benzoic acid esters against Candida albicans strains. Nat Prod Res. 2018;32:572575. https://doi.org/10.1080/14786419.2017.1317776

25. Lin YS, Chen CR, Wu WH, Wen CL, Chang CI, Hou WC. Anti- $\alpha$-glucosidase and antidipeptidyl peptidase-IV activities of extracts and purified compounds from Vitis thunbergii var. taiwaniana. J Agr Food Chem. 2015;63:6393-6401. https://doi.org/10.1021/acs.jafc.5b02069

26. Morocho V, Valle A, García J, Gilardoni G, Cartuche L, Suárez AI. $\alpha$-Glucosidase inhibition and antibacterial activity of secondary metabolites from the Ecuadorian species Clinopodium taxifolium (Kunth) Govaerts. Molecules. 2018;23:146.

https://doi.org/10.3390/molecules23010146 
27. Hu WJ, Yan L, Park D, Jeong HO, Chung HY, Yang JM et al. Kinetic, structural and molecular docking studies on the inhibition of tyrosinase induced by arabinose. Int J Biol Macromol. 2012;50:694-700. https://doi.org/10.1016/j.ijbiomac.2011.12.035

28. Meng Y, Su A, Yuan S, Zhao H, Tan S, Hu C et al. Evaluation of total flavonoids, myricetin, and quercetin from Hovenia dulcis Thunb. as inhibitors of $\alpha$-amylase and $\alpha$-glucosidase.

Plant Foods Hum Nutr. 2016;71:444-449. https://doi.org/10.1007/s11130-016-0581-2 
Figures
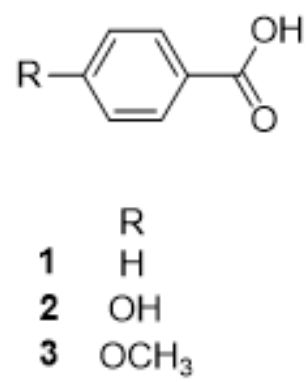

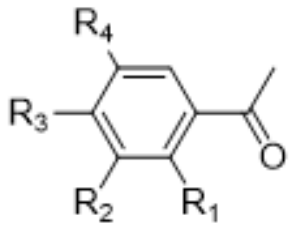

$\begin{array}{llll}R_{1} & R_{2} & R_{3} & R_{4}\end{array}$ $4 \mathrm{OH} \quad \mathrm{H} \quad \mathrm{OH} \quad \mathrm{H}$ $5 \mathrm{OH} \quad \mathrm{H} \quad \mathrm{OCH}_{3} \quad \mathrm{H}$ $6 \mathrm{H} \mathrm{OH} \mathrm{OCH} \mathrm{H}_{3}$

$7 \mathrm{OH} \quad \mathrm{H} \quad \mathrm{CH}_{3} \mathrm{OH}$

$8 \mathrm{OH} \mathrm{H} \mathrm{OCH}_{3} \mathrm{OH}$

$9 \mathrm{OH} \mathrm{OH} \mathrm{OCH} \mathrm{OH}_{3}$<smiles>[R]C(=O)c1cc(O)c(O)c(O)c1</smiles>

$10 \mathrm{OH}$

$11 \mathrm{OCH}_{3}$

Figure 1

Phytochemical constituents 1-11 from Paeonia suffruticosa 

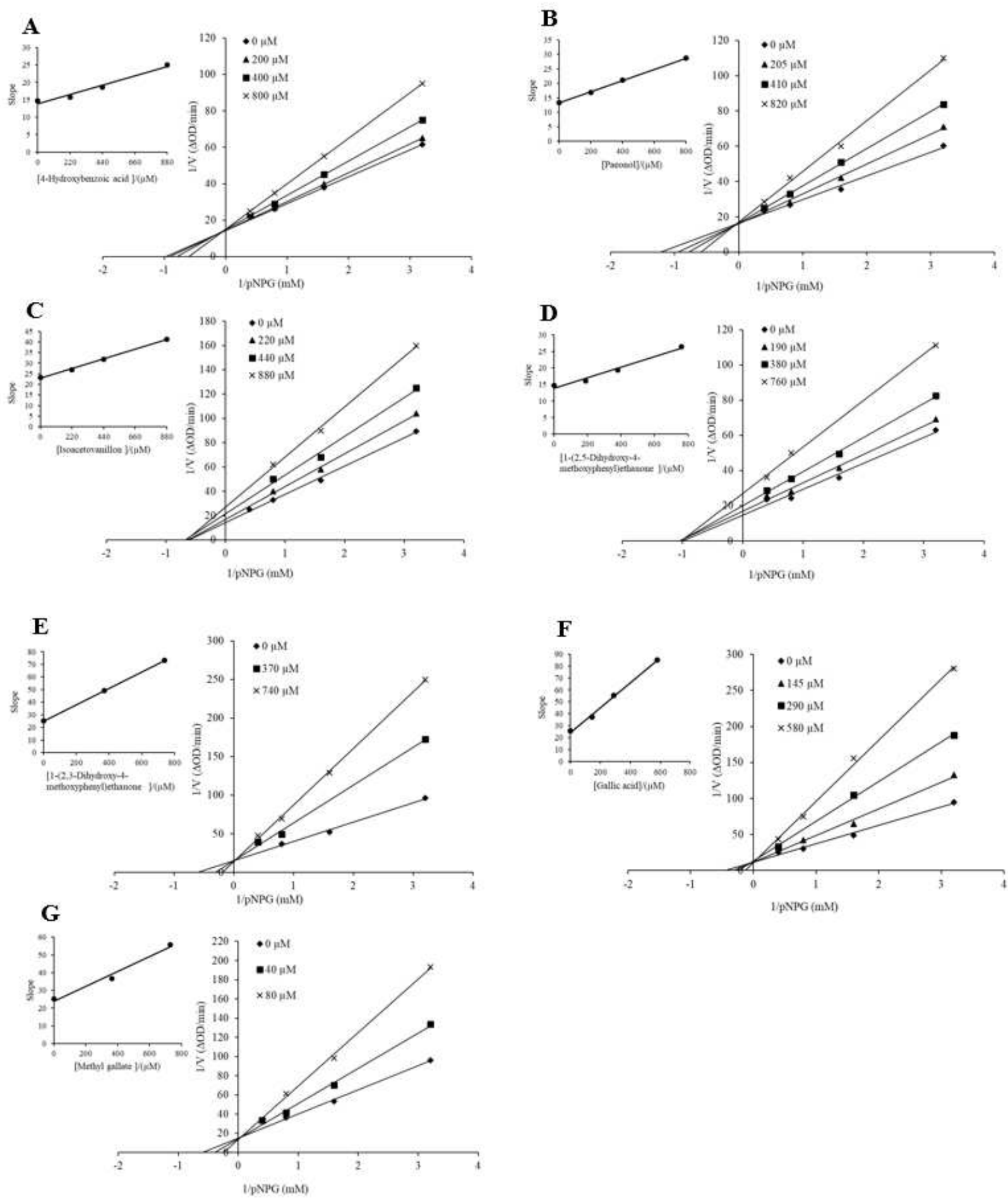

\section{Figure 2}

The lineweaver-Burk plots of the active constituents of Paeonia suffruticosa root bark against aglucosidase with pNPG as substrate. Insert represent the secondary plots of slope versus compounds. (A) 4-Hydroxybenzoic acid (2), (B) Paeonol (5), (C) Isoacetovanillon (6), (D) 1-(2,5-Dihydroxy-4methoxyphenyl)ethanone (8), (E) 1-(2,3-Dihydroxy-4-methoxyphenyl)ethanone (9), (F) Gallic acid (10), (G) Methyl gallate (11). 

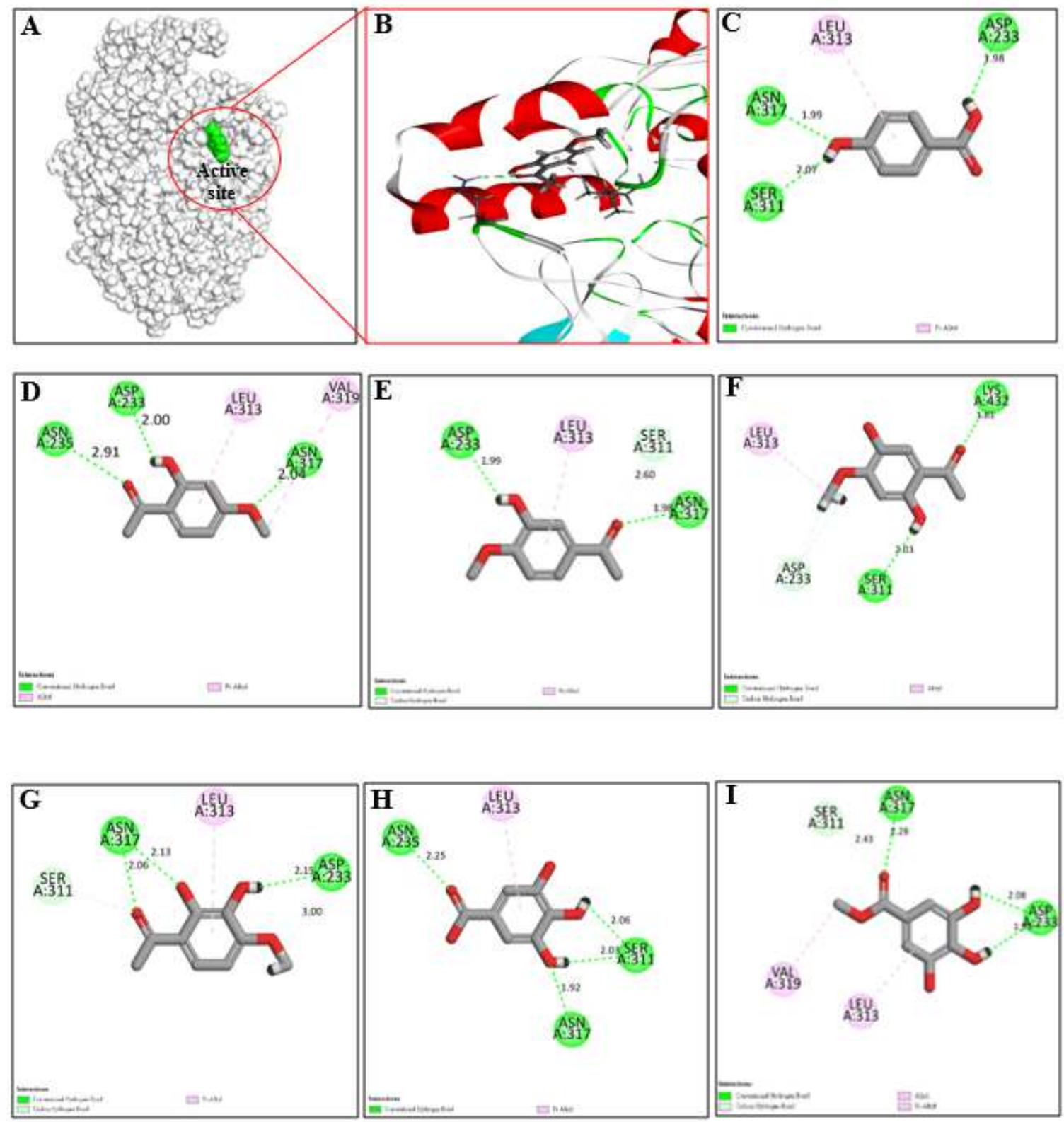

\section{Figure 3}

Predominant interactions observed between the compounds and main residues of a-glucosidase. (A) The green region indicate the catalytic active site of a-glucosidase. (B) The compounds docked to enzyme on the molecular surface. (C) 4-Hydroxybenzoic acid (2), (D) Paeonol(5), (E) Isoacetovanillon (6), (F) 1-(2,5Dihydroxy-4-methoxyphenyl)ethanone (8), (G) 1-(2,3-Dihydroxy-4-methoxyphenyl)ethanone (9), (H) Gallic acid (10), (I) Methyl gallate (11).

\section{Supplementary Files}

This is a list of supplementary files associated with this preprint. Click to download. 
- MCRSupplementaryMaterial.docx

- Table.pdf 